\title{
Metástasis cutánea en carcinoma vesical de células transicionales
}

\author{
Luján Marco S, Bango García V, Gimeno Argente V, Bosquet Sanz M, Vera Donoso CD, \\ Jiménez Cruz JF.
}

Servicio de Urología. Hospital Universitario La Fe. Valencia.

Actas Urol Esp. 2008;32(3):369

$\mathrm{V}$ arón de 64 años que acude a urgencias por linfedema en extremidades inferiores, junto con lesiones papulosas y pruriginosas en hipogastrio y muslo derecho (Fig. 1). Como antecedentes destaca tumor vesical infiltrante (pT2bG3) diagnosticado hace 6 años, tratado mediante quimio-radioterapia con criterios de respuesta completa. Hace 16 meses recaída local (pT3aG3NxMx), practicándose cistoprostatectomia radical más derivación urinaria tipo Bricker. Se toma muestra para anatomía patológica de la lesión verrugosa (Fig. 2), con el diagnóstico de metástasis de carcinoma transicional (Fig. 3).

Correspondencia autor: Dr. S. Luján Marco

Servicio de Urología. Hospital Universitario La Fe

Avda. Campanar, 21 - 46009 Valencia. Tel.: 963862700

E-mail autor: slujanmarco@comv.es

Información artículo: Imágenes en Urología

Trabajo recibido: noviembre 2006

Trabajo aceptado: diciembre 2006

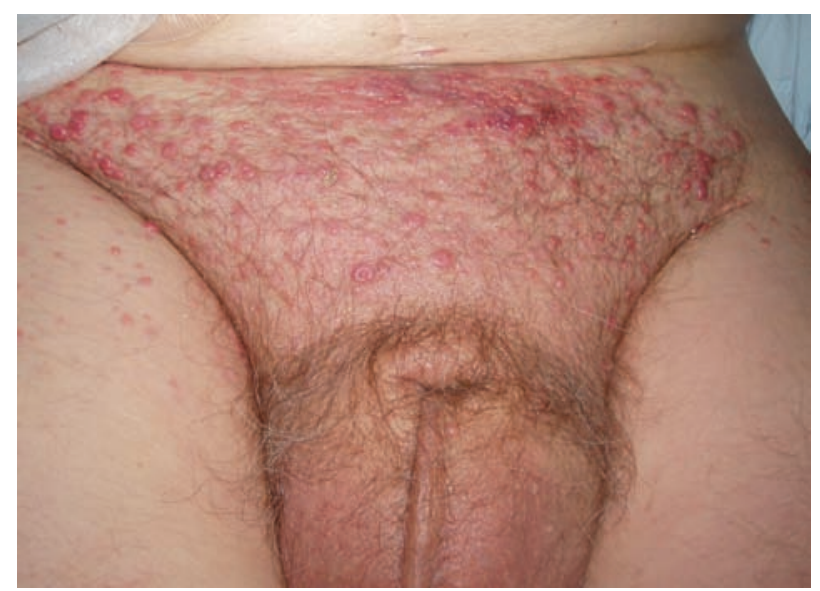

FIGURA 1. Imagen de las lesiones papulosas de aspecto verrucoso sobre hipogastrio y muslo derecho.

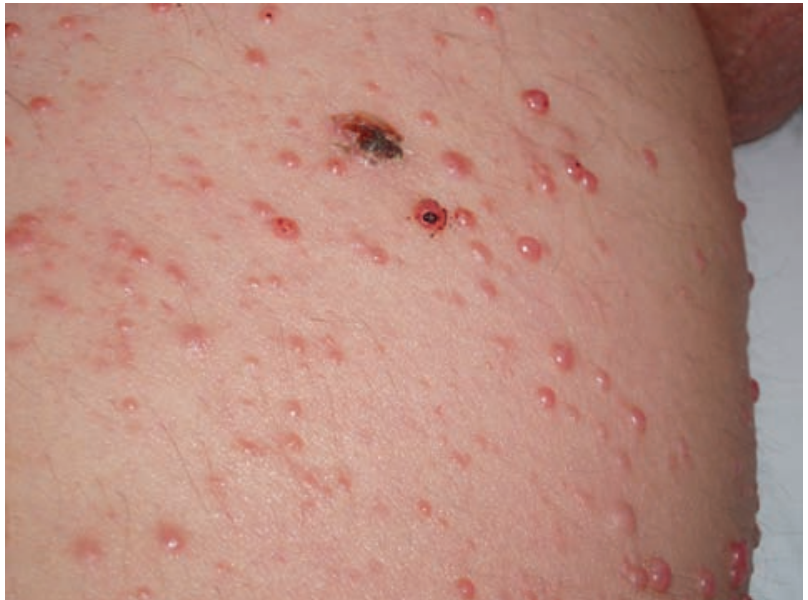

FIGURA 2. Detalle de las lesiones sobre muslo derecho que fueron biopsiadas

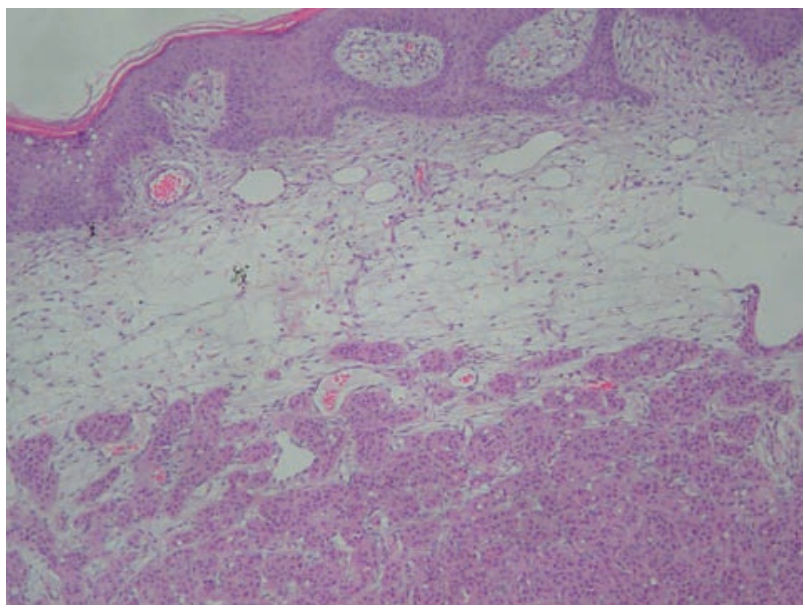

FIGURA 3. Tinción con hematoxilina-eosina de la lesión. De parte superior a inferior se distingue, estrato córneo, crestas epidérmicas, dermis y debajo de esta, acúmulo de células con múltiples atipias nucleares compatibles con metástasis de carcinoma transicional. 